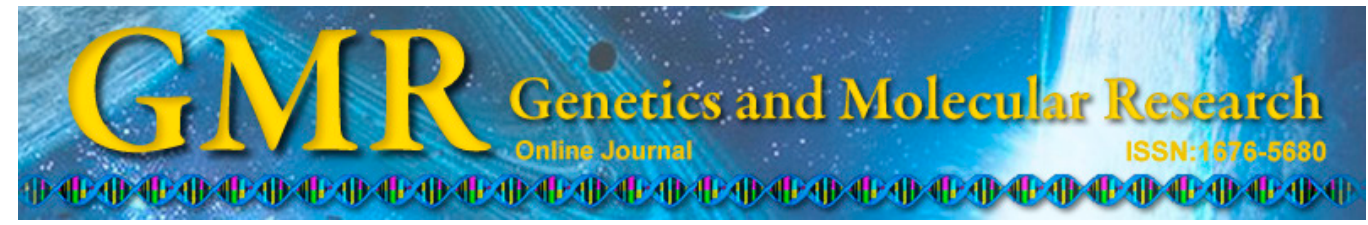

\title{
Cytogenetic description of Ancistrus abilhoai (Siluriformes: Loricariidae) from Iguaçu River basin, southern Brazil
}

\author{
M.O. Ribeiro ${ }^{1}$, R.B. Noleto ${ }^{1}$, C.A. Lorscheider ${ }^{1}$, F.E. Porto ${ }^{2}$, A.C. Prizon ${ }^{2}$, \\ C.H. Zawadzki ${ }^{3}$, L.C. Oliveira ${ }^{4}$ and A.L.B. Portela Castro ${ }^{2}$ \\ ${ }^{1}$ Departamento de Ciências Biológicas, \\ Universidade Estadual do Paraná, União da Vitória, PR, Brasil \\ ${ }^{2}$ Departamento de Biotecnologia, Genética e Biologia Celular, \\ Universidade Estadual de Maringá, Maringá, PR, Brasil \\ ${ }^{3}$ Departamento de Biologia/Nupélia, \\ Universidade Estadual de Maringá, Maringá, PR, Brasil \\ ${ }^{4}$ Departamento de Ciências Biológicas, \\ Universidade Estadual do Mato Grosso, Alta Floresta, MT, Brasil \\ Corresponding author: M.O. Ribeiro \\ E-mail: marcosotavio87@hotmail.com
}

Genet. Mol. Res. 14 (2): 4051-4057 (2015)

Received July 30, 2014

Accepted December 8, 2014

Published April 27, 2015

DOI http://dx.doi.org/10.4238/2015.April.27.20

ABSTRACT. The Iguaçu River basin is a tributary to the upper
Paraná River in southern Brazil, and is considered an important
aquatic ecoregion that, although having few species of fish, $51-71 \%$
of these are apparently endemic. Ancistrus abilhoai is one of three
recently described species for this basin and is currently considered
endemic to the basin. In this study, we present the chromosomal
structure of two populations of Ancistrus abilhoai one collected in
the Iguaçu River, in Paraná State, and another collected in the Timbó
River, a tributary of the Iguaçu River, in the State of Santa Catarina.
Karyotype analyzes were performed in 11 specimens from the Iguaçu
River (four females and seven males) and 12 specimens (all males) 
from Timbó River, revealing $2 \mathrm{n}=48$ chromosomes with a karyotype formula of $22 \mathrm{~m}+14 \mathrm{sm}+6 \mathrm{st}+6 \mathrm{a}$ in both populations. Analysis of active nucleolar organizer regions (Ag-NORs) and fluorescent in situ hybridization (FISH) with $18 \mathrm{~S}$ rDNA probes revealed the submetacentric pair 13 bearing marks at terminal positions on the short arms. Considered as plesiomorphic chromosomal markers in Loricariidae, asynteny $18 \mathrm{~S}$ and $5 \mathrm{~S}$ rDNA, and small amounts of heterochromatin were observed. In this study, the first chromosomal data of A. abilhoai are presented with comments on karyotypic characteristics of the genus.

Key words: Ancistrini; Heterochromatin; Karyotype evolution; rDNA

\section{INTRODUCTION}

Ancistrini Kner, 1854 was resurrected by Amrbruster (2004) as a tribe of the Hypostominae subfamily, and consists of 24 genus and approximately 200 species. Along with Hypostomoni, this tribe has the larger number of species. Among Ancistrini, Ancistrus is the most diverse and is composed of 65 valid species (Bifi et al., 2009; Froese and Pauly, 2014). Although the Iguaçu River basin contains relatively few species of fish, it was classified as an important aquatic ecoregion, since 51 to $71 \%$ of those species are apparently endemic (Abell et al., 2008). Three recently described Ancistrus species are found in the Iguaçu River basin: Ancistrus abilhoai (Figure 1), A. agostinhoi, and A. mullerae. A. abilhoai is limited to the upper and middle Iguaçu river portions (Bifi et al., 2009), is classified as an endemic species, and is very rare and hard to find (Baumgartner et al., 2012).

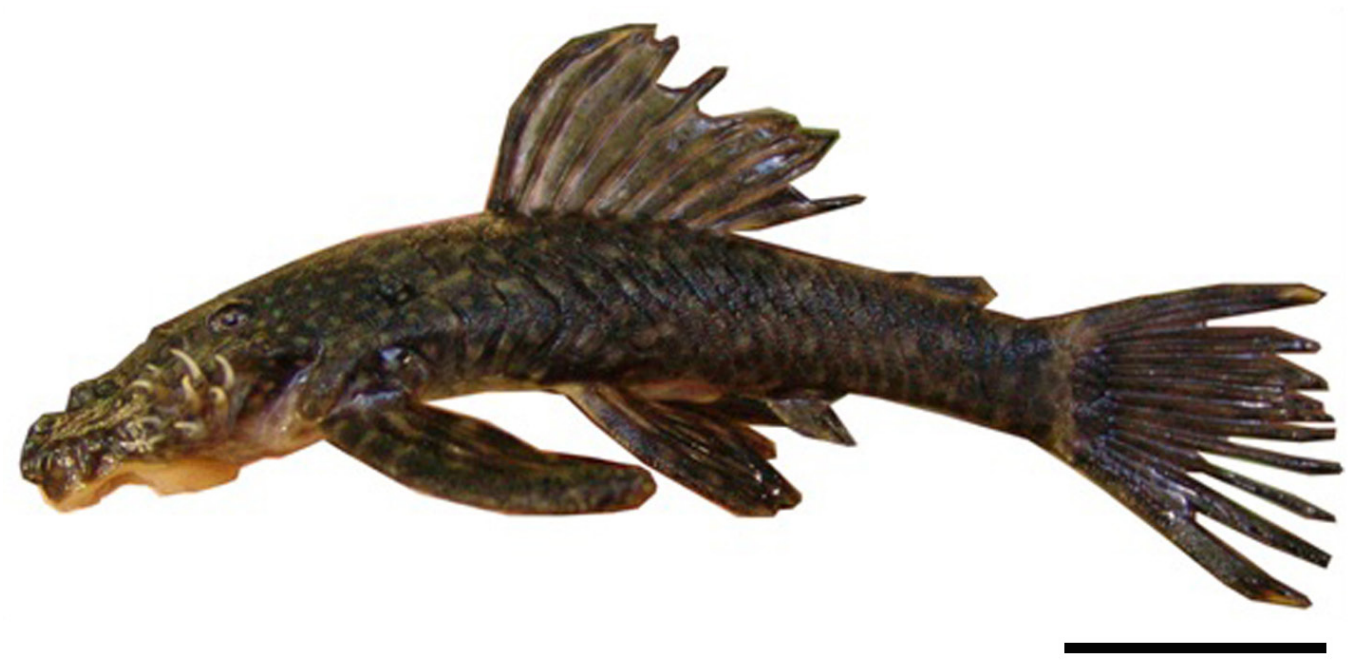

Figure 1. Specimen of Ancistrus abilhoai from the Iguaçu River basin. Bar $=20 \mathrm{~mm}$. 
In previous cytogenetic papers regarding Ancistrus, the $2 \mathrm{n}$ ranged from 34 chromosomes in A. cuiabae to 54 chromosomes in A. claro (Alves et al., 2003; Souza et al., 2004; Alves et al., 2005; Mariotto and Miyazawa, 2006; de Oliveira et al., 2006, 2007, 2008; Mariotto et al., 2004, 2011). Artoni and Bertollo (2001) suggested that a diploid number of 54 chromosomes was the ancestral condition for loricariids. Nevertheless, this number is rare in the Hypostominae subfamily and specifically within Ancistrini, whose members have $2 \mathrm{n}$ values $\leq 54$ chromosomes, suggesting that centric fusions in particular, contributed to the karyotype evolution of this tribe (Mariotto et al., 2011).

In the present study, cytogenetic data from two populations of A. abilhoai from the Iguaçu River basin are presented. The description of the karyotypic structure of a recently described and putative endemic species is an important reference that contributes to our understanding of the chromosomal evolution in this genus.

\section{MATERIAL AND METHODS}

Twenty-three $A$. abilhoai individuals from the two populations were analyzed: 11 specimens from the Iguaçu River $\left(26^{\circ} 15^{\prime} 64^{\prime \prime S}\right.$; $\left.51^{\circ} 06^{\prime} 28^{\prime \prime} \mathrm{W}\right)$, in the municipality of União da Vitória, Paraná State; and 12 specimens from the Timbó River (26³0'37"S; 5046'55"W), a tributary of the Iguaçu River, in the municipality of Santa Cruz do Timbó, Santa Catarina State. Voucher specimens were deposited in Coleção Ictiológica do Nupélia - Núcleo de Pesquisas em Limnologia, Ictiologia e Aquicultura, Universidade Estadual de Maringá, Maringá, Paraná, Brazil (NUP-14679). The sex of the animals was determined by gonadal examination.

Chromosomal preparations were obtained from anterior kidney cells following in vivo colchicine treatment (Bertollo et al., 1978). Chromosome nomenclature was in accordance with that described by Levan et al. (1964). Constitutive heterochromatin was detected by the C-banding method (Sumner, 1972) as well as by combined staining with 4'-6-diamin2-phenylindole (DAPI) and chromomycin $\mathrm{A}_{3}\left(\mathrm{CMA}_{3}\right)$ (Schweizer, 1980). Nucleolar organizer regions (NOR) were identified by Ag-NOR staining (Howell and Black, 1980) and by fluorescent in situ hybridization (FISH) (Heslop-Harrison et al., 1991). The dual-color FISH technique was performed with an 18S rDNA probe from Prochilodus argenteus Spix and Agassiz (Hatanaka and Galetti Jr., 2004) and a 5S rDNA probe from Leporinus elongatus Valenciennes (Martins and Galetti Jr., 1999). The probes 18S and 5S were labeled with biotin-14-dATP and digoxigenin-11-dUTP, respectively. Both were labeled by nick translation according to manufacturer instructions (Roche Diagnostics, Basel, Switzerland). The detection and amplification of hybridization signals were carried out using an avidin-FITC conjugate (Sigma-Aldrich, St. Louis, MO, USA) and anti-digoxigenin rhodamine (Roche). FISH signals were analyzed in a Zeiss Axiophot epifluorescence microscope, and the chromosome images were captured by the Case Data Manager Expo 4.0 (Applied Spectral Imaging, MigdalHa'emek, Israel) software.

\section{RESULTS}

Both A. abilhoai populations exhibited a diploid number of $2 \mathrm{n}=48$ chromosomes, consisting of 22 metacentric, 14 submetacentric, 6 subtelocentric, and 6 acrocentric chromosomes, with a fundamental number of 90 (Figure 2). 
(a)
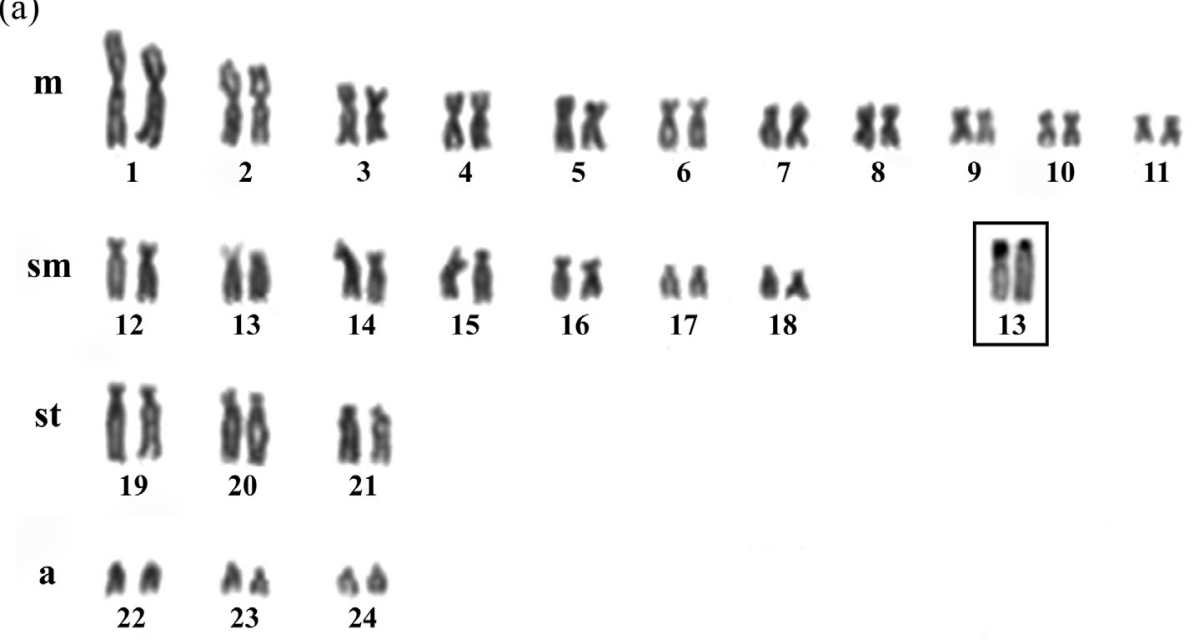

(b)

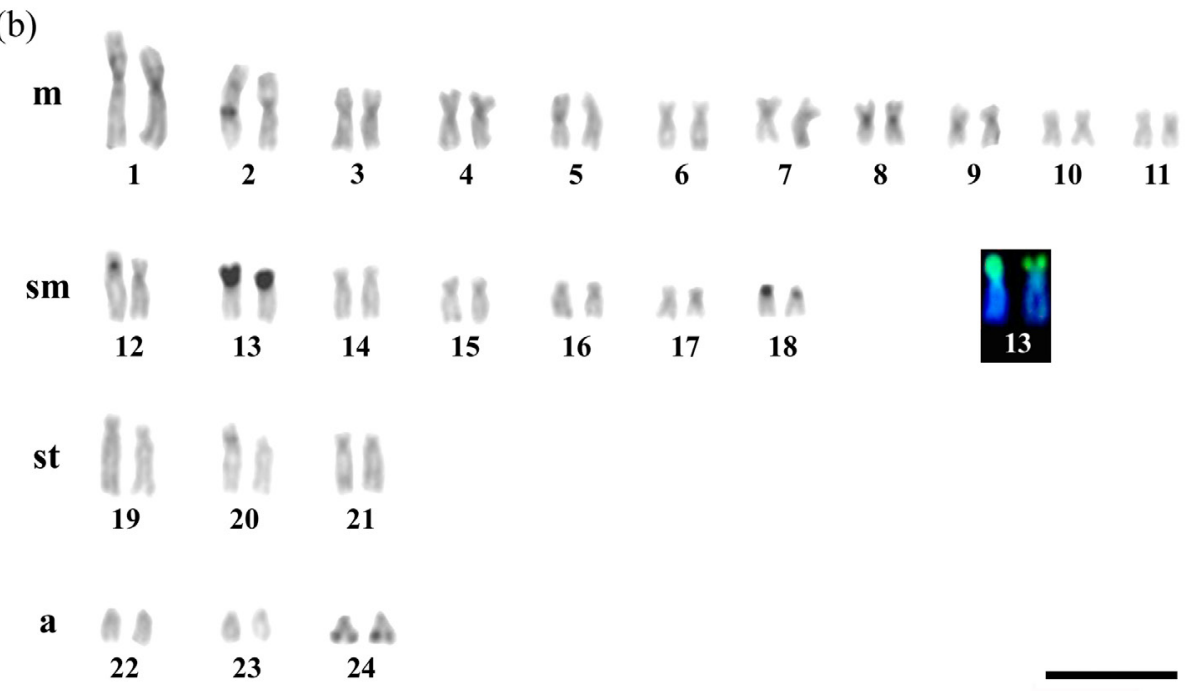

Figure 2. Karyotypes of Ancistrus abilhoai arranged from Giemsa-stained (a) and C-banding (b). The NOR-bearing chromosome pair is shown after silver impregnation (white boxes) and DAPI/CMA3 staining (black boxes). Bar $=10 \mu \mathrm{m}$.

The C-banding technique revealed constitutive heterochromatin restricted to the centromeric region on all chromosomes, in the telomeric region of pair 24, and in the extension of the short arm of chromosome pair 13 (Figure 2). This last pair bears 45S rDNA genes as identified by silver nitrate (Ag-NOR) staining and by $\mathrm{CMA}_{3} / \mathrm{DAPI}$ fluorochromes (Figures 2 boxes).

Dual-color FISH using 18S and 5S rDNA probes showed adjacent co-localization of these sequences on the short arms of the submetacentric chromosomal pair 13, which is associated with heterochromatic regions (Figure 3). 

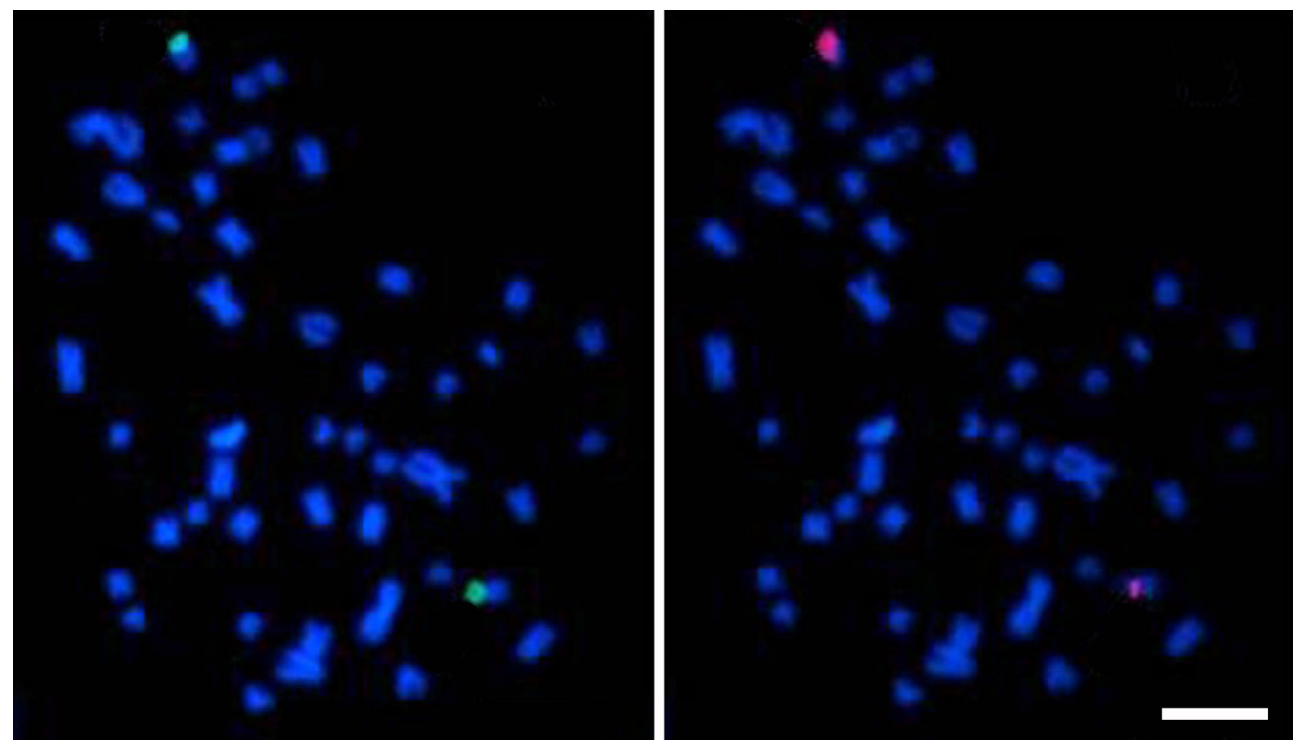

Figure 3. Metaphase of Ancistrus abilhoai after double-FISH using 18S rDNA (green signal) and 5S rDNA (red signal) probes. $\mathrm{Bar}=10 \mu \mathrm{m}$.

\section{DISCUSSION}

These data from Ancistrus revealed that seven of 27 species have the diploid number of $2 n=52$ chromosomes. A karyotype with 48 chromosomes is uncommon in the genus and up to now was only observed in three species, two of them from Iguaçu River basin - Ancistrus sp and A. abilhoai (analyzed in the present work), and in A. ranunculus from the Xingu River, in the Amazonas state. The presence of diploid numbers less than 52 suggests the predominance of Robertsonian chromosomal rearrangements (centric fusion) in the karyotypic evolution of this genus (Alves et al., 2003), although rearrangements such as pericentric inversions and translocations have also had an effect on the chromosomal evolution of this group. These rearrangements could explain the existence of many karyotypes with higher numbers of acrocentric chromosomes (de Oliveira et al., 2009, Mariotto et al., 2011).

The Iguaçu River is an environmentally heterogeneous river with some taxa presenting a relatively high diversity such as the characid Astyanax (Garavello and Sampaio, 2010), the siluriform Trichomycterus (de Pinna, 1992), and the loricariid Hypostomus (Garavello et al., 2012). Due to the high cytogenetic diversity found in Ancistrus whether in the Amazon basin (de Oliveira et al., 2009) or in the Paraguay basin (Mariotto et al., 2011), some degree of variability could be present in two allopatric populations of Ancistrus in the high heterogeneous Iguaçu River basin. However, no differences were observed among the individuals from the two sites analyzed in this study. This result indicates that populations from the Iguaçu River channel are genetically similar to, and probably have contact with, the population from Timbó River. However, if they are currently isolated from each other, the isolation is a very recent event.

According to our results, the use of FISH techniques and silver-staining, the NORs were found to be adjacent or embedded in C-banded heterochromatin. The association between 
constitutive heterochromatin and rDNA cistrons has been frequently reported in Neotropical Actinopterygii (Galetti, 1998). The NORs staining by specific GC fluorochromes is related to the presence of ribosomal RNA genes packaged in heterochromatic structures (Pendás et al., 1993; Artoni and Bertollo, 1999). The synteny of the 18S and 5S ribosomal genes has also been found in other species of Ancistrus. Mariotto et al. (2011), suggest that the A. claro karyotype with $2 \mathrm{n}=54$ chromosomes and synteny for rDNA genes could represent the primitive condition for this genus.

Considering the wide diversity of diploid number within Ancistrus, the karyotype found in A. abilhoai, with $2 \mathrm{n}=48$ chromosomes, simple NORs and synteny for $5 \mathrm{~S}$ and $45 \mathrm{~S}$ rDNA loci, represent a combination of primitive and derived characters. Therefore, integrative studies are important for modern systematic analysis, and cytogenetic approaches might be useful to better clarify our knowledge on the evolutionary history of this fish group.

\section{ACKNOWLEDGMENTS}

Research supported by Conselho Nacional de Desenvolvimento Científico e Tecnológico (CNPq) and Universidade Estadual de Maringá (UEM). Nupélia provided logistic support.

\section{REFERENCES}

Abell R, Thieme ML, Revenga C, Bryer M, et al. (2008). Freshwater ecoregions of the world: a new map of biogeographic units for freshwater biodiversity conservation. BioScience 58: 403-414.

Alves AL, Oliveira C and Foresti F (2003). Karyotype variability in eight species of the subfamilies Loricariinae and Ancistrinae (Teleostei, Siluriformes, Loricariidae). Caryologia 56: 57-63.

Alves AL, Oliveira C and Foresti F (2005). Comparative cytogenetic analysis of eleven species of subfamilies Neoplecostominae and Hypostominae (Siluriformes: Loricariidae). Genetica 124: 127-136.

Armbruster JW (2004). Phylogenetic relationships of the suckermoutharmoured catfishes (Loricariidae) with emphasis on the Hypostominae and the Ancistrinae. Zool. J. Linn. Soc. 141: 1-80.

Artoni RF and Bertollo LAC (1999). Nature and distribution of constitutive heterochromatin in fishes, genus Hypostomus (Loricariidae). Genetica 106: 209-214.

Artoni RF and Bertollo LAC (2001). Trends in the karyotype evolution of Loricariidae fish (Siluriformes). Hereditas 134: 201-210.

Baumgartner G, Pavanelli CS, Baumgartner D, Bifi AG, et al. (2012). Peixes do Baixo Iguaçu. Maringá, Eduem, 129.

Bertollo LAC, Takahashi CS and Moreira-Filho O (1978). Cytotaxonomic consideration on Hopliaslacerdae (Pisces, Erythrinidae). Braz. J. Genet. 1: 103-120.

Bifi AG, Pavanelli CS and Zawadzki CH (2009). Three new species of Ancistrus Kner, 1854 (Siluriformes: Loricariidae) from the Rio Iguaçu basin, Paraná State, Brazil. Zootaxa 2275: 41-59.

de Oliveira RR, Souza IL and Venere PC (2006). Karyotype description of three species of Loricariidae (Siluriformes) and occurrence of the ZZ/ZW sexual system in Hemiancistrusspilomma Cardoso \& Lucinda, 2003. Neotropical Ichthyol. 4: 93-97.

de Oliveira RR, Feldberg E, Anjos MB and Zuanon J (2007). Karyotype characterization and ZZ/ZW sex chromosome heteromorphism in two species of the catfish genus Ancistrus Kner, 1854 (Siluriformes: Loricariidae) from the Amazon basin. Neotropical Ichthyol. 5: 301-306.

de Oliveira RR, Feldberg E, Anjos MB and Zuanon J (2008). Occurrence of multiple sexual chromosomes (XX/XY, $Y_{2}$ and $\mathrm{Z}_{1} \mathrm{Z}_{1} \mathrm{Z}_{2} \mathrm{Z}_{2} / \mathrm{Z}_{1} \mathrm{Z}_{2} \mathrm{~W}_{1} \mathrm{~W}_{2}$ ) in catfishes of the genus Ancistrus (Siluriformes, Loricariidae) from the Amazon Basin. Genetica 134: 243-249.

de Oliveira RR, Feldberg E, Anjos MB and Zuanon J (2009). Mechanisms of chromosomal evolution and its possible relation to natural history characteristics in Ancistrus catfishes (Siluriformes: Loricariidae). J. Fish Biol. 75: 2209-2225.

de Pinna MCC (1992). Trichomycterus castroi, a new species of trichomycterid catfish from the Rio Iguaçu of Southeastern Brazil (Teleostei: Siluriformes). Ichthyol. Explor. Freshwaters 3: 89-95. 
Froese R and Pauly D (2014). Fishbase. World Wide Web Electronic Publication. Eletronic Version. Available at [http:// www.fishbase.org/search.php]. Accessed July 22, 2014.

Galetti Jr PM (1998). Chromosome diversity in neotropical fishes: NOR studies. Italian J. Zool. 65: 53-56.

Garavello JC and Sampaio FAA (2010). Five new species of genus Astyanax Baird \& Girard, 1854 from Rio Iguaçu, Paraná, Brazil (Ostariophysi, Characiformes, Characidae). Braz. J. Biol. 70: 847-865.

Garavello JC, Britski HA and Zawadzki CH (2012). The cascudos of the genus Hypostomus Lacépède (Ostariophysi: Loricariidae) from the Rio Iguaçu basin. Neotropical Ichthyol. 10: 263-283.

Hatanaka T and Galetti Jr PM (2004). Mapping of the 18S and 5S ribosomal RNA genes in the fish Prochilodus argenteus Agassiz 1829 (Characiformes, Prochilodontidae). Genetica 122: 239-244.

Heslop-Harrison JS, Schwarzacher T, Anamthawat-J'onsson K, Leitch AR, et al. (1991). In situ hybridization with automated chromosome denaturation. Technique 3: 109-115.

Howell WM and Black DA (1980). Controlled silver staining of nucleolus organizer regions with a protective colloidal developer: a 1-step method. Experientia 36: 1014-1915.

Levan A, Fredga K and Sandberg AA (1964). Nomenclature for centromeric position on chromosomes. Hereditas 52: 201-220.

Martins C and Galetti Jr PM (1999). Chromosomal localization of 5S rDNA genes in Leporinus fish (Anostomidae, Characiformes). Chromosome Res. 7: 363-367.

Mariotto S and Miyazawa CS (2006). Ancistrus cf. dubius (Siluriformes, Ancistrinae), a complex of species. Chromosomal characterization of four populations and occurrence of sex chromosomes of the type XX/XY, in the Pantanal Basin of Mato Grosso, Brazil. Caryologia 59: 299-304.

Mariotto S, Artoni RF and Miyazawa CS (2004). Occurrence of sexual chromosome, of the type ZZ/ZW, in Ancistrus cf. Dubius (Loricariidae, Ancistrinae) of the Paraguay River Basin, Mato Grosso, Brazil. Caryologia 57: 327-331.

Mariotto S, Centofante L, Vicari MR, Artoni RFA, et al. (2011). Chromosomal diversification in ribosomal DNA sites in Ancistrus Kner, 1854 (Loricariidae, Ancistrini) from three hydrographic basins of Mato Grosso, Brazil. Comp. Cytogenet. 5: 289-300.

Pendás AM, Móran P and Garcia-Vazquez E (1993). Ribosomal RNA genes are interspersed throughout a heterocromatin chromosome arm in Atlantic salmón. Cytogenet. Cell Genet. 63: 128-130.

Schweizer D (1980). Simultaneous fluorescent staining of R-bands and specific heterochromatic regions (DAPI bands) in human chromosomes. Cytogenetic Cell Genet. 27:190-193.

Souza ACP, Nascimento AL, Carvalho JR, Barros RMS, et al. (2004). Karyotypic analysis of Baryancistrus aff. niveatus (Ancistrinae, Loricariidae) by C-banding, Ag-Nor, $\mathrm{CMA}_{3}$, DAPI and FISH. Caryologia 57: 219-223.

Sumner AT (1972). A simple technique for demonstrating centromericheterocromatin. Exp. Cell Res. 25: 304-306. 